\title{
PENTINGNYA KEBIJAKAN K3 DALAM RUANG LINGKUP KEPERAWATAN
}

\author{
Sri Lailan Nazmi Saragih \\ Email : lailansaragih9@gmail.com
}

\begin{abstract}
ABSTRAK
Kebijakan K3 merupakan komitmen pimpinan suatu organisasi perusahaan untuk menjamin Keselamatan dan Kesehatan Kerja seluruh personil di bawah kendalinya juga pihak-pihak yang berkaitan (berhubungan) dengan kegiatan (aktivitas) operasi perusahaan (organisasi) tersebut. Pelaksanaan Kesehatan dan Keselamatan Kerja (K3) adalah salah satu bentuk upaya untuk menciptakan tempat kerja yang aman, sehat, bebas dari pencemaran lingkungan, sehingga dapat mengurangi dan atau bebas dari kecelakaan kerja dan penyakit akibat kerja yang pada akhirnya dapat meningkatkan efisiensi dan produktivitas kerja. Kebijakan K3 dalam keperawatan sangat penting untuk meningkatkan derajat kesehatan baik itu pasien atau perawat sendiri baik fisik, mental, maupun social. Untuk itu didalam jurnal ini nantinya akan saya bahas dan jelaskan mengenai pentingnya kebijakan $\mathrm{k} 3$ dalam keperawatan.
\end{abstract}

\section{Kata Kunci : K3, Rumah Sakit, Keperawatan}

\begin{abstract}
$K 3$ policy is the commitment of the leadership of a company organization to ensure the occupational safety and health of all personnel under their control as well as those associated with the organization's activities. The implementation of Occupational Health and Safety (K3) is one form of effort to create a work place that is safe, healthy, free from environmental pollution, so as to reduce or free from occupational accidents and occupational diseases which in turn can increase work efficiency and productivity. Health and safety policies in nursing are very important to improve the health status of both the patient or the nurse, both physically, mentally and socially. For this reason, in this journal I will later discuss and explain the importance of K3 policies in nursing.
\end{abstract}

Keywords: K3, Hospital, Nursing 


\section{LATAR BELAKANG}

Keselamatan dan kesehatan kerja bagi pekerja di rumahsakit dan fasilitas medis lainnya perlu di perhatikan. Demikian pula penanganan faktor potensi berbahaya yang ada di rumah sakit serta metode pengembangan program keselamatan dan kesehatan kerja disana perlu dilaksanakan, seperti misalnya perlindungan baik terhadap penyakit infeksi maupun non-infeksi, penanganan limbah medis, penggunaan alat pelindung diri dan lain sebagainya. Selain terhadap pekerja di fasilitas medis/klinik maupun rumah sakit, Keselamatan dan Kesehatan Kerja di rumah sakit juga "concern" keselamatan dan hak-hak pasien, yang masuk kedalam program patient safety.

Perawat adalah suatu profesi yang mulia, karena memerlukan kesabaran dan ketenangan dalam melayani pasien yang sedang menderita sakit. Seorang perawat harus dapat melayani pasien dengan sepenuh hati. Sebagai seorang perawat harus dapat memahami masalah yang dihadapi oleh klien, selain itu seorang perawat dapat berpenampilan menarik. Untuk itu seorang perawat memerlukan kemampuan untuk memperhatikan orang lain, ketrampilan intelektual, teknikal dan interpersonal yang tercermin dalam perilaku perawat.

Kondisi Keselamatan dan Kesehatan Kerja (K3) perusahaan di Indonesia secara umum diperkirakan termasuk rendah. Pada tahun 2005 Indonesia menempati posisi yang buruk jatuh di bawah Singapura, Malaysia, Filipina, dan Thailand. Padahal kemajuan perusahaan sangat ditentukan peranan mutu tenaga kerjanya karena perhatian perusahaan, pemerintah juga perlu memfasilitasi dengan peraturan atau aturan perlindungan Keselamatan dan Kesehatan Kerja. Faktor Keselamatan Kerja menjadi penting karena sangat terkait dengan kinerja karyawam dan ada gilirannya pada kinerja perusahaan. Semakin tersedianya fasilitas keselamatan kerja semakin sedikit kemungkinan terjadinya kecelakaan kerja.

Usaha yang dapat dilakukan untuk meminimalkan risiko gangguan kesehatan dan keselamatan kerja dari aktivitas pekerjaan yang dilakukan perawat yaitu pengelolaan risiko atau dikenal dengan manajemen risiko. Menurut standar Australia/New Zealand (2004), pada dasarnya manajemen risiko bersifat pencegahan terhadap terjadinya kerugian maupun kecelakaan kerja. Langkahlangkah pengelolaan risiko dilakukan secara berurutan yang bertujuan untuk membantu dalam pengambilan keputusan yang lebih baik dengan melihat risiko dan dampak yang kemungkinan ditimbulkan. Tujuan dari manajemen risiko itu sendiri adalah meminimalkan kerugian dengan urutan terdiri dari penentuan konteks, identifikasi risiko, analisis risiko, evaluasi risiko, pengendalian risiko, monitor dan evaluasi, serta komunikasi dan konsultasi.

\section{METODE}

Pengkajian ini menggunakan metode kualitatif yang dilakukan dengan cara mengumpulkan sebanyak-banyaknya data untuk dianalisis, yaitu dengan menggunakan literature view yang berkenaan dengan judul pembahasan yaitu mengenai pentingnya kebijakan k3 dalam keperawatan. Adapun 
Literature View yang digunakan adalah Buku Teks, Buku Referensi, Jurnal Elektronik, Reasearch, dan hasil skripsi. Dengan kata kunci K3, Rumah Sakit, dan Keperawatan. Dan Literature View yang digunakan dalam metode ini adalah sebanyak 11 Literature View yang diterbitkan 8 tahun terakhir.

\section{HASIL}

Berdasarkan Literature View yang saya baca, bukan hanya Rumah Sakit yang harus mementingkan Kebijakan K3 namun dalam ruang lingkup keperawatan sendiri juga harus memikirkan tentang kebijakan K3. Perawat dituntut untuk memeahami secara luas tentang kebijakan K3 ini. Dalam pembahasan ini dapat memberikan masukan bagi perawat pelaksana dan juga tenaga kesehatan yang ada di rumah sakit untuk lebih meningkatkan perilaku dalam menjaga keselamatan diri dari bahaya fisik biologis, kimia, ergonomik, psikososial, dan luka-luka akibat benda tajam, maupun dari transmisi infeksi. Strategi yang dapat dilakukan adalah dengan mengikuti pelatihan-pelatihan yang dapat meningkatkan terkait keselamatan di rumah sakit, dan juga seorang dapat menerapkan semua sikap yang akan di berikan kepada pasien demi menjaga keselamatan pasien adalah dengan menerapkan sikap tersebut juga di kesehariannya dengan orang-orang yang ada di sekitarnya pula.pengetahuan dan keterampilan perawat serta lebih patuh terhadap peraturan dan kebijakan.

Dalam pelaksanaan tugas sebagai seorang perawat, perawat tidak boleh lupa pada
Konsep Kesehatan Dan Keselamatan Kerja. Pelaksanaan Kesehatan dan Keselamatan Kerja (K3) adalah salah satu bentuk upaya untuk menciptakan tempat kerja yang aman, sehat, bebas dari pencemaran lingkungan, sehingga dapat mengurangi dan atau bebas dari kecelakaan kerja dan penyakit akibat kerja yang pada akhirnya dapat meningkatkan efisiensi dan produktivitas kerja.

Kecelakaan kerja tidak saja menimbulkan korban jiwa maupun kerugian materi bagi pekerja dan pengusaha, tetapi juga dapat mengganggu proses produksi secara menyeluruh, merusak lingkungan yang pada akhirnya akan berdampak pada masyarakat luas.

\section{PEMBAHASAN}

Kesehatan dan Keselamatan Kerja (K3) adalah suatu program yang dibuat sebagai upaya mencegah timbulnya kecelakaan dan penyakit akibat kerja dengan cara mengenali hal-hal yang berpotensi menimbulkan kecelakaan dan penyakit akibat kerja serta tindakan antisipatif apabila terjadi kecelakaan dan penyakit akibat kerja. Upaya penanganan faktor potensi berbahaya yang ada di rumah sakit serta metode pengembangan program kesehatan dan keselamatan kerja perlu dilaksanakan, seperti misalnya perlindungan baik terhadap penyakit infeksi maupun non-infeksi, penanganan limbah medis, penggunaan alat pelindung diri dan lain sebagainya. 


\section{A. Defenisi K3}

K3RS (Keselamatan dan Kesehatan Kerja Rumah Sakit) adalah segala kegiatan untuk menjamin dan melindungi keselamatan dan kesehatan bagi sumber daya manusia rumah sakit, pasien, pendamping pasien, pengunjung, maupun lingkungan rumah sakit melalui upaya pencegahan kecelakan kerja dan penyakit akibat kerja di rumah sakit.

\section{B. Kebijakan K3}

Kebijakan K3 yang berkaitan dengan keperawatan di Indonesia Relevansi kebijakan K3 Nasional dengan tugas perawat :

1. Pemberi asuhan keperawatan

2. Penyuluh dan konselor bagi klien

3. Pengelola pelayanan keperawatan

4. Peneliti keperawatan

5. Pelaksanaan tugas berdasarkan pelimpahan wewenang

6. Pelaksanaan tugas dalam keterbatasan tertentu

\section{Peran Perawat dalam Penerapan K3 dalam Keperawatan}

Tugas yang dilakukan oleh seorang perawat dalam pelaksanaan pelayanan kesehatan kerja antara lain berupa tugas administrasi dan pelaporan, tugas pemeliharaan dan perawatan kesehatan serta tugas penyuluhan/ pelatihan/ pendidikan kesehatan, keselamatan kerja yang diberikan kepada seluruh tenaga kerja. Perawat memberikan keterangan tentang pelaksanaan pelayanan kesehatan kerja kepada pegawai pengawas keselamatan dan kesehatan kerja bila diperlukan.

Disamping itu perawat perlu mengetahui arah dan tujuan perusahaan secara umum, merencanakan dan menerapkan program beserta evaluasinya, dan dapat mengembangkan kemampuan menajerialnya, selaras dengan pengetahuan kedokteran yang tlah dimilikinya.

Dengan demikian, perawat yang memimpin suatu unit pelayanan kesehatan kerja harus mampu menjalin kerja sama dengan pihak pengurus perusahaan, tenaga kerja, dinas atau instansi terkait dan tetap berpedoman pada etika profesinya.

Peranan perawat pada program Kesehatan dan Keselamatan Kerja bisa dikatakan sangat bermakna,mengingat tugas fungsional perawat dalam K3 begitu luas. Bisa dikatakan bahwa fokus utamaperawatan kesehatan kerja adalah kesehatan dan keselamatan kerja bagi tenaga kerja denganpenekanan pada pencegahan terjadinya penyakit dan cidera. Hal ini senada dengan tujuan K3.Hanya saja perawatan kesehatan kerja di Indonesia belum seperti yang diharapkan. Hal ini terjadi/antara lain karena perkembangan yang sangat pesat dari industri di Indonesia dan perkembangan fasilitas pendidikan di bidang kesehatan dan keselamatan kerja yang ada diIndonesia. Pengaruh lain adalah hambatan jenjang pendidikan dasar perawat yang berbedabeda.Peranan profesi dalam mengembangkan tingkat profesi- 
onalisme belum terlihat bermakna. Untukmenjaga mutu profesionalisme, sudah saatnya kita semua memikirkan upaya yang perlu dilakukan.Salah satunya diharapkan organisasi profesi meningkatkan peranannya dalam membina danmemantau anggotanya, serta menerus aktif dalam meningkatkan kemampuan dan keterampilan anggotanya.

\section{KESIMPULAN}

Peranan perawat dalam pelaksanaan Kesehatan dan Keselamatan Kerja bisa dikatakan sangat bermakna mengingat tugas fungsional perawat dalam K3 begitu luas. Bisa dikatakan bahwa fokus utama perawatan kesehatan kerja adalah kesehatan dan keselamatan kerja bagi tenaga kerja dengan penekanan pada pencegahan terjadinya penyakit dan cidera. Hal ini senada dengan tujuan K3. Hanya saja perawatan kesehatan kerja di Indonesia belum seperti yang diharapkan. Hal ini terjadi/antara lain karena perkembangan yang sangat pesat dari industri di Indonesia dan perkembangan fasilitas pendidikan di bidang kesehatan dan keselamatan kerja yang ada di Indonesia.

\section{SARAN}

Perawat mengetahui fungsi dan peran seorang perawat dan disarankan berkerja dengan memperhatikan fungsi dan perannya tersebut.
Kesehatan dan keselamatan kerja sangat penting dalam pembangunan karena sakit dan kecelakaan kerja akan menimbulkan kerugian ekonomi (lost benefit) suatu perusahaan atau negara olehnya itu kesehatan dan keselamatan kerja harus dikelola secara maksimal bukan saja oleh tenaga kesehatan tetapi seluruh masyarakat.

\section{DAFTAR PUSTAKA}

Ike, H., Irennius, V., \& Syahriani, U. (2018). Studi Kebijakan, Perencanaan, dan Pelaksanaan Keselamatan dan Kesehatan Kerja RS di Rumah Sakit Mitra Sejati Medan. Jurnal Mutiara Kesehatan Masyarakat, 3(2).

Ivana, A., Widjasena, B., \& Jayanti, S. (2014). Analisa Komitmen Manajemen Rumah Sakit Terhadap Keselamatan dan Kesehatan Kerja pada RS PRIMA Medika Pemalang. Jurnal Kesehatan Masyarakat, 2(1), 36-38.

Maria, S., Wiyono, J., \& Candrawati, E. (2015). Kejadian Kecelakaan Kerja Perawat Berdasarkan tindakan tidak aman. Jurnal Care, 3(2).

Nazirah, R., \& Yuswardi. (2017). Perilaku Perawat dalam Penerapan Manajemen Kesehatan dan Keselamatan Kerja (K3) DI Aceh. Idea Nursing Journal, 8(3).

Putri, D., \& Setyo, A. (2017). Pengetahuan, Sikap, Kebijakan K3 dengan 
Penggunaan Alat Pelindung Diri. Jurnal of Health Education, 2(1).

Rifai, M. (2017). Hubungan Pengetahuan dan Partisipasi Keselamatan dan Kesehatan Kerja pada Perawat dengan Kejadian Kecelakaan Kerja di Rumah Sakit. Jurnal Publikasi Kesehatan Masyarakat Indonesia, 4(3).

Sholihah, Q., Johan, A., \& Djohan. (2013). Keselamatan dan Kesehatan Kerja RS, K3RS : Meminimalisis Kecelakaan dan Penyakit akibat kerja di RS. Malang: Universitas Brawijaya Press.

Simamora, R. (2012). Buku Ajar Manajemen Keperawatan . Jakarta: EGC.

Simamora, R. (2018). Buku Ajar Keselamatan Pasien melalui Timbang Terima Pasien berbasis Komunikasi Efektif : SBAR. Medan: USU Press.

Simamora, R. (2019). Buku Ajar Pelaksanaan Identifikasi Pasien. Uwais Inspirasi Indonesia.

Tukatman, Sulistiawati, Purwaningsih, \& Nursalam. (2015). Analisis Keselamatan dan Kesehatan Kerja Perawat dalam Penanganan Pasien di RS Benyamin Guluh Kab Kolaka. Jurnal Ners, 10(2).

Zimbri, E., Pinontoan, O. R., \& Mndley, S. (2020). Faktor Psikologi dan Perilaku dengan Pebnerapan Manajemen Keselamatan Kerja Rumah Sakit. Jurnal of Public
Health and Community Medicine, 1(3), 20-24. 